IP Periodica Polytechnica

Transportation Engineering

46(2), pp. 95-100, 2018

https://doi.org/10.3311/PPtr.11414

Creative Commons Attribution (i)

RESEARCH ARTICLE

\section{Ranking of Dry Ports in Europe - Benchmarking}

\author{
Judit Oláh ${ }^{1}$, Steffen Nestler ${ }^{2}$, Thomas Nobel ${ }^{3}$, József Popp ${ }^{4 *}$
}

Received 24 August 2017; accepted 20 September 2017

\begin{abstract}
Deutsche GVZ-Gesellschaft (DGG) establishes the first ranking of Freight Villages (dry ports) throughout Europe. The study assesses the level of development of the European Freight Villages by a method oriented on the benchmarking approach. The results of this process build the first ranking of Freight Villages (FV) on an European level. The study will help to provide more transparency to the market segment of international logistics centres and is oriented to give a positive impulse to the further successful European development of sustainable macrologistics concepts. As a kind of a side effect this comparison shall also allow a networking among the FV'S Europe-wide, supported by better knowledge and access to significant information of the market position and strategies of the individual locations.
\end{abstract}

\section{Keywords}

freight village, dry port, logistics services, benchmarking, macro logistics concept, hinterland, intermodal terminal

\footnotetext{
${ }^{1}$ Institute of Applied Informatics and Logistics,

Faculty of Economics and Business, University of Debrecen, H-4032 Debrecen, Hungary

${ }^{2}$ Deutsche GVZ-Gesellschaft mbH, G-28359 Bremen, Germany

${ }^{3}$ Institute of Shipping Economics and Logistics,

Department Logistic Systems, G-28359 Bremen, Germany

${ }^{4}$ Institute of Sectoral Economics and Methodology,

Faculty of Economics and Business, University of Debrecen,

H-4032 Debrecen, Hungary

*Corresponding author, e-mail: popp.jozsef@econ.unideb.hu
}

\section{Introduction}

The development of dry ports, an important component of intermodal transport, could play a major role in promoting intermodal transport (Hanaoka and Regmi, 2011). With the increase of containerised traffic, container terminals have started to develop in new locations in the hinterland of seaports (Korovyakovsky and Panova, 2011).

However, despite the emerging popularity of the dry port concept, very little research has been done on the assessment of development of dry ports in European countries. The goal of this paper is to support the transfer of positive effects on national and European level that are generated by dry ports on local and regional levels. The first European ranking (2010) showed the enormous interest of many dry port actors to get insights and information concerning market positioning and strategies of individual dry ports in Europe. Regarding the assessment of development of the dry ports in Germany and Europe, DGG conducts regularly extensive data collections. The collected data allows a profound overview of the status quo of the investigated dry ports (national or international) and allows the creation of a ranking to identify for example best practices.

\section{Literature review}

One of the imperative issues of dry port development in developing economies is location planning. While the minimization of set up costs and total logistics costs are key factors in dry port location analysis, there are also other more qualitative location factors driven by multiple stakeholders involved like operators, users and the community (Notteboom and Rodrigue, 2009; Nguyen and Notteboom, 2016). As a rule, the dry ports are located along the developed transport corridors (Panova and Hilmola, 2015). Dry port location planning requires a thorough decision making process as it is too costly to relocate the facility in the short term.

Many models used for facility location attach a substantial role to transport costs in view of finding the optimal location (Nguyen and Notteboom, 2016). Usually located at strategic places near gateway seaports, industrial areas or along major transportation axes, dry port plays significant roles in 
optimizing all activities to ensure cargoes can be delivered from one end to another in an efficient manner (Juhel, 1999).

However, while a number of research works investigating the locational characteristics and spatial dynamics of dry ports in Western, advanced economies exist (Rutten, 1998; Hesse, 2004; Hesse and Rodrigue, 2004; Rahimi et al., 2008; Notteboom and Rodrigue, 2009; Roso et al., 2009). The role of port as a driving force of the development of local and regional economies, both in developing (Omiunu, 1989), and developed countries (Witherick, 1981) is widely accepted by many scholars (Hilling, 2005; Ducruet, 2009). Development of dry ports reduces customs costs, improves rail-sea intermodal capacity, and minimizes transportation time $(\mathrm{Ng}$ and Cetin, 2012; Wang et al., 2016).

At the same time, port enterprises are paying more and more attention to the construction of dry ports ( $\mathrm{Li} \&$ Jiang, 2014). In addition to reduce the port's spatial and environmental pressure and to lessen the congestion of highway transport, the main purpose of a dry port is to extend the port hinterland by improving the facilities of the inland distribution centre, which closely integrate the maritime and inland freight depots (Shi and Li, 2016).

\section{Matherial and methods}

But even after this first rough sorting of possible locations, several hundred locations in thirty countries all over Europe and even beyond were assessed in the benchmarking process. Following more detailed criteria of separation, about 100 locations were finally analysed. The study could benefit from a high level of response at the individual locations. The study was thus able to revert to comprehensive data of more than 70 Freight Villages. Regarding this situation, the quality and quantity of the survey is unique and after the given state of knowledge it is the first of its kind. The analyses are based on a questionnaire with 29 assessment criteria (benchmarks/key performance indicators), especially developed by the DGG.

\section{Methodology of the benchmarking process}

Those criteria (according to the emphasis) indicate the base for the benchmark and the ranking. The weighting of the assessment criteria was continuously analyzed in the course of the benchmarking process at all FV's to allow the ideal mapping of the status quo (Fig. 1).

An assessment criteria was e.g. the proportion between the developed area and the area of the whole site. Following the assessment of this criteria, in the European average about $70 \%$ of the surface in the individual locations are already eveloped. In a corridor of $60 \%$ up to $80 \%$ developed area, a surveyed location was than indicated as "developed on an average". If the location was already developed completely or up to more than $80 \%$, the value in the benchmarking process in this specific criteria was correspondingly "above average".

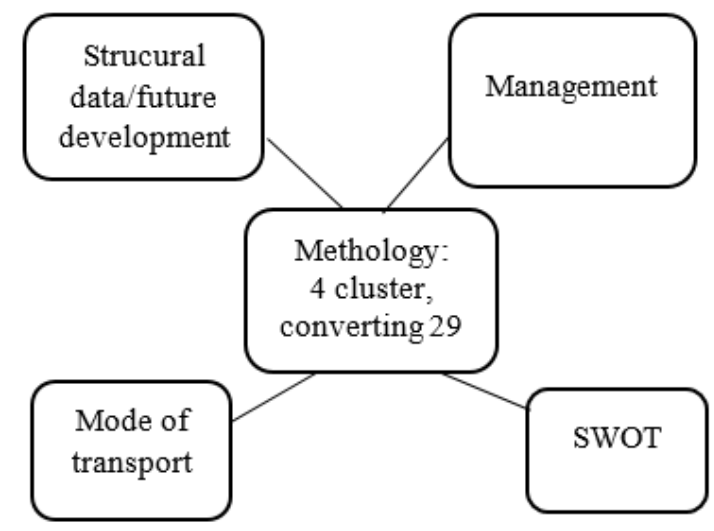

Fig. 1 Benchmarking methodology

\section{Results}

The first finding of the survey was the heterogeneous understanding of the Freight Village concept. Generally, a Freight Village shall be defined as

a. Settlement of transport-oriented (independent) companies, logistics service providers and logistics-intensive trade and production enterprises in a commercial area.

b. Freight Villages should contain an intermodal road/rail or inland waterway/road/rail terminal with open access to every potential user.

c. Locations with commercial and non-commercial synergy potentials for the tenants, including the establishment of suitable organisational structures (i.e. FV development company is recommended).

This general definition had to be adopted to fit the most varying European situation. To find a consistent and agreeable definition of a Freight Village applicable in every European country was therefore the first task of the study. To set the Freight Village locations apart from other industrial areas mainly with settlers from the transport and logistics sector, a strong focus was put on the intermodality of the area, which means the interface of at least two modes of transport, in general road and rail. A second strong emphasis was put on the role of the management company and the prevailing service structures. Following these two criteria, only logistics centers have been taken into account, which met those points and served as a real logistics node.

Therefore, most of the so called "Logistic Parks" or the commercial and distribution parks that are mainly situated close to the highways without the possibility to change the mode of transport by the means of an intermodal terminal were not further considered. Also some traditional inland ports did not meet the criteria of the commitment of a management company and as a result also did not take part in the benchmarking process (Table 1).

One of the main outcomes of the benchmarking (Fig. 2-3, Table 2) summed up in a ranking, was that the Italian Interporti”, 
Table 1 Benchmarking indicators

\begin{tabular}{|c|c|c|c|c|}
\hline & $\begin{array}{l}\text { Structure and State of } \\
\text { Development }\end{array}$ & Factor & $\begin{array}{l}\text { Max. } \\
\text { value }\end{array}$ & $\begin{array}{l}\text { Max. } \\
\text { performance } \\
\text { points }\end{array}$ \\
\hline 1 & Total area & 2 & 3 & 6 \\
\hline 4 & $\begin{array}{l}\text { Status of site } \\
\text { development }\end{array}$ & 3 & 3 & 9 \\
\hline 5 & Expandability & 4 & 3 & 12 \\
\hline 6 & Enterprises settled & 3 & 3 & 9 \\
\hline 7 & Employees per ha & 6 & 3 & 18 \\
\hline 14 & $\begin{array}{l}\text { Structure (centralised } \\
\text { / decentralized) }\end{array}$ & 3 & 2 & 6 \\
\hline
\end{tabular}

\begin{tabular}{|c|c|c|c|c|}
\hline & Management & Factor & $\begin{array}{l}\text { Max. } \\
\text { value }\end{array}$ & $\begin{array}{l}\text { Max. } \\
\text { performance } \\
\text { points }\end{array}$ \\
\hline 17 & Refinincing activities & 5 & 3 & 15 \\
\hline \multirow[t]{2}{*}{19} & Level of service & 6 & 3 & 18 \\
\hline & Mode of Transport & Factor & $\begin{array}{l}\text { Max. } \\
\text { value }\end{array}$ & $\begin{array}{l}\text { Max. } \\
\text { performance } \\
\text { points }\end{array}$ \\
\hline \multirow[t]{2}{*}{25} & Capacity utilisation & 3 & 3 & 9 \\
\hline & SWOT & Factor & $\begin{array}{l}\text { Max. } \\
\text { value }\end{array}$ & $\begin{array}{l}\text { Max. } \\
\text { performance } \\
\text { points }\end{array}$ \\
\hline 28 & $\begin{array}{l}\text { Strengths } \\
\text { /Opportunities }\end{array}$ & 5 & 3 & 15 \\
\hline 29 & $\begin{array}{l}\text { Weaknesses } \\
\text { / Threats }\end{array}$ & 2 & 3 & 6 \\
\hline
\end{tabular}

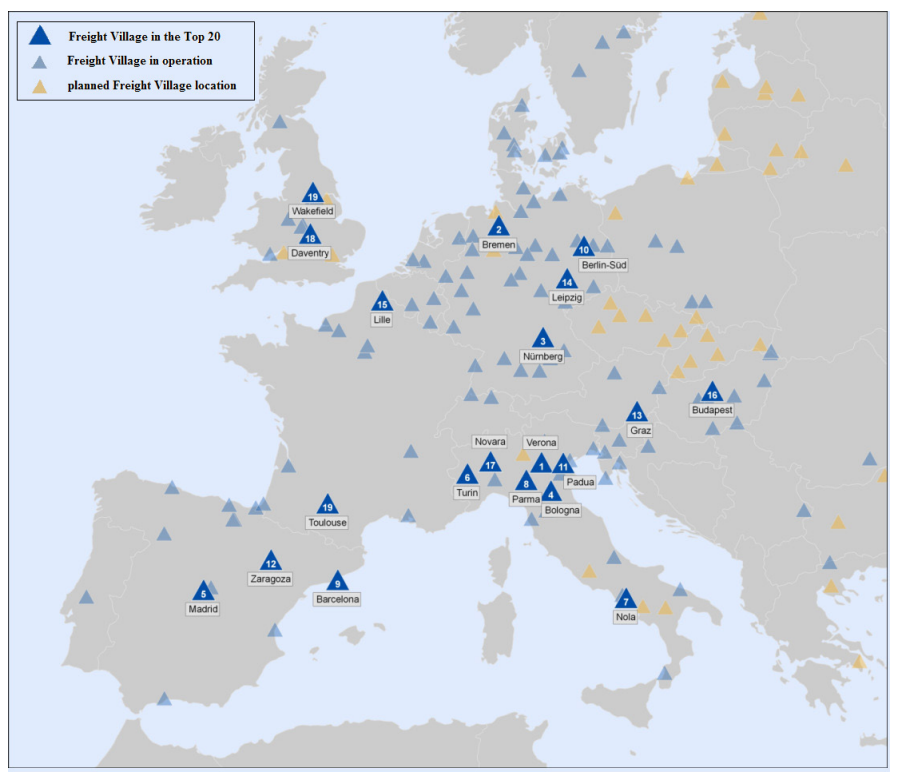

Fig. 2 Location of top 20 dry ports (Fright Villages)

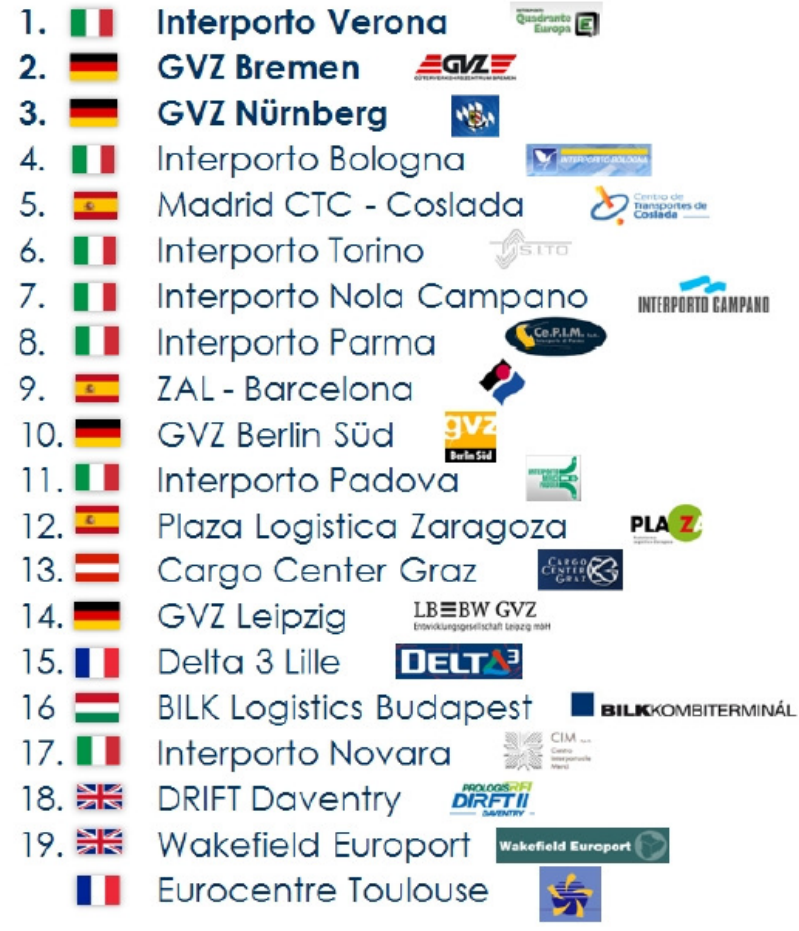

Fig. 3 Ranking of TOP 20 dry ports in Europe

German "Güterverkehrszentren" and Spanish Transport Centres take a leading role in the European Freight Village landscape, and set the standards of good performance (best practice).

Those three countries form the "peer group" of the assessed locations and are placed among the first ten. Topnof the ranking is the Interporto di Verona, one of the most important intermodal nodes in Europe and thus the number 1. Also most of the highly ranked European locations have a strong focus on the intermodal interchange between the transport modes road and rail, building the most important intermodal hubs in their countries. The European Freight Villages are hence the supporting pillars of the combined transport network.

The German Freight Villages have been assessed already twice in the recent years by the DGG. In comparison with this national ranking, the locations Bremen and Nuremberg (2nd and 3rd position) could hold their good positions or even improve further. Speaking in European terms, these two locations are not only winner of the "national league" but now also are in the best group within the "Champions League". The German locations get their qualification also due to their high amount of people directly employed in the Freight Villages, compared with other Logistics Centres in Europe.

This high figure (and therefore high value within the benchmarking analysis) is closely linked to the great amount of value added services performed in the German Freight Villages. Those services ask for a lot of manpower. This finding corresponds with the rather high amount of outsourced logistic services in Germany. The Freight Village of Bremen leads within this criteria with about 8.000 employees - an outstanding figure in Europe. 
The "best in class" performance of the Italian Interporti are based on their high quality of their management structures. Italian Freight Village management companies offer a wide range of possible services, e.g. several services regarding logistics real estate (like warehouses or other storage facilities) and a high level of manpower dedicated to the administration and supervision of the area. Especially in the important European freight corridors crossing the Alps, the Italian Freight Villages serve as a gateway grouping the cargo. Those are their "benchmarks".

The other country of the peer group, Spain, offers successful Freight Village activities in several regions. Especially in the high density area of Madrid and Barcelona (5th and 9th position in the ranking), capable Freight Villages have been developed in the last years. Also the Basque region has recently become a new "hot spot" for logistics activities, taking the pace in the ranking. But also in France and in the UK, adjacent to the central places and close to the area of high population density, Freight Villages that serve mainly as distribution centres have attracted important manufacturers, trade companies and logistics service providers.

The Freight Villages is mainly shaped by the well established locations in Western and Southern Europe. Only slowly the establishment of the Freight Village concept in the Eastern European countries gets off the ground. Within these countries, those locations better progressed where the public authorities have taken a leading role in the development of Freight Village strategies. A positive example in this regard is Hungary, providing 13 Freight Village locations. In some of the other Eastern European countries (e.g. in Poland), that have only started to develop binding concepts, the market for logistic real estate is quite mature, hindering the implementation of further locations with intermodal terminal as well as logistic intensive trade (shipper potential). Sometimes, the designation of area to Freight Villages is done in special economic zones.

Regarding the important criteria of the management company, mainly three approaches can be distinguished in Europe:

- Mostly in the early developments in the Eastern European countries, the development is mostly driven by the demand of the market and pushed mainly by private actors. A best practice example of this approach can also be found in the UK. Adjacent to the intermodal terminals designated by the "Strategic Rail Freight Interchange Policy", settlement areas for logistics services were established by private development agencies, developing the logistics real estate on their own risk according to the public style guide, the public standard for the development.

- On the other side of the axis, there are as well locations which have been mostly developed by public authorities, in most of the cases of the regional authorities in co-operation with the national responsible stakeholders. This public approach was formerly prevailing e.g. in Italy, but is now rather seldom chosen.
- In Germany, one of the scientific initiator of the Freight Village concept, the locations are developed and operated by a Public Private Partnership (PPP). Mostly, the lease of land plots is done by a management company of such a FV, if this management company is the owner of the area or do have a capacious right of use, to refinance the activities of the area by this income of lease. The rent of logistics facilities like warehouses, container storage area and safe parking space may also be a possible source of income, provided that the management company own the facilities or do have a sufficient equity base. The public body provides in this approach the land plot and the pri vate partners are responsible for the service and the entrepreneurial activities, achieving the income.

Following the public approach as well as the PPP approach, the marketing of the area is done by one entity, providing an institutional face to the possible customer. These marketing activities correspond also to supra-regional networks of the private stakeholders and regional initiatives (like logistic platforms). Also, both approaches use public funding to establish the intermodal terminal.

\subsection{Complete Ranking}

Table 2 Ranking of dry ports in Europe

\begin{tabular}{|c|c|c|}
\hline Ranking & Location & Performance \\
\hline 1 & I - Interporto Verona & 211 \\
\hline 2 & D - GVZ Bremen & 209 \\
\hline 3 & D - GVZ Nürnberg & 205 \\
\hline 4 & I - Interporto Bologna & 202 \\
\hline 5 & E - Madrid CTC-Coslada & 199 \\
\hline 6 & I - Interporto Torino & 198 \\
\hline 7 & I - Interporto Nola Campano & 195 \\
\hline 8 & I - Interporto Parma & 190 \\
\hline 9 & E - ZAL Barcelona & 189 \\
\hline 10 & D - GVZ Berlin Süd & 188 \\
\hline 11 & I - Interporto Padova & 187 \\
\hline 12 & E - Plaza Logistica Zaragoza & 186 \\
\hline 13 & A - Cargo Center Graz & 185 \\
\hline 14 & D - GVZ Leipzig & 175 \\
\hline 15 & F - Delta 3 Lille & 174 \\
\hline 16 & H - BILK Logistic Budapest & 170 \\
\hline 17 & I - Interporto Novara & 169 \\
\hline 18 & GB - DRIFT Daventry & 167 \\
\hline 19 & GB - Wakefield & 165 \\
\hline 20 & F - Eurocentre Toulouse & 165 \\
\hline 21 & D - GVZ Berlin West & 163 \\
\hline 22 & H - Szolnok & 162 \\
\hline 23 & D - GVZ Dresden & 157 \\
\hline
\end{tabular}




\begin{tabular}{|c|c|c|}
\hline 24 & KR - Zagreb Free Zone & 157 \\
\hline 25 & F - Parc de Trigance Istres & 156 \\
\hline 26 & A - ALPLOG Kärten & 156 \\
\hline 27 & I - Interporto Puglia & 153 \\
\hline 28 & A - Ennshafen & 153 \\
\hline 29 & GB - BIRFT Birmingham & 152 \\
\hline 30 & D - GVZ Südwestsachsen & 152 \\
\hline 31 & $\mathrm{H}$ - Freeport of Budapest & 151 \\
\hline 32 & E - ZAISA Irun & 148 \\
\hline 33 & D - GVZ Regensburg & 148 \\
\hline 34 & D - GVZ Emsland & 147 \\
\hline 35 & D - GVZ Emschler & 145 \\
\hline 36 & KR - Free Zone Kukuljanovo & 145 \\
\hline 37 & D - GVZ Berlin Ost & 144 \\
\hline 38 & GB - TIRFT Telford & 144 \\
\hline 39 & E - Barcelona CÍM Vales & 142 \\
\hline 40 & NL - Europark Coevoerden & 141 \\
\hline 41 & I - Interporto Rivalta Scrivia & 141 \\
\hline 42 & SR - Free Zone Pirot & 140 \\
\hline 43 & D - GVZ Kassel & 140 \\
\hline 44 & GB - CIRFT Cardiff & 140 \\
\hline 45 & CH - GVZ Embraport & 139 \\
\hline 46 & F - Garonor Aulnay-Sous-Bois & 139 \\
\hline 47 & GB - Doncaster & 139 \\
\hline 48 & F - Rouen Vallee de Seine & 137 \\
\hline 49 & D - GVZ Trier & 134 \\
\hline 50 & H - Logisztar & 134 \\
\hline 51 & PL - Gliwice & 133 \\
\hline 52 & GB - SIRFT Sheffield & 130 \\
\hline 53 & B - Arlon & 129 \\
\hline 52 & GB- Hams Hall & 129 \\
\hline 55 & E - Bilbao Aparkabisa & 128 \\
\hline 56 & PL - Euroterminal Slawkow & 127 \\
\hline 57 & KR - Free Zone Pula & 126 \\
\hline 58 & I - Interporto Abruzzo & 125 \\
\hline 59 & I - Interporto Rovigo & 123 \\
\hline 60 & DK - Koge & 114 \\
\hline 61 & PL - Pomeranian LC & 113 \\
\hline 62 & DK - Gata Way E45 Velje & 110 \\
\hline 63 & B - Liege Triologieport & 109 \\
\hline 64 & D - GVZ ETTC & 104 \\
\hline 65 & PL- Konin & 98 \\
\hline 66 & LT - Vilnius & 89 \\
\hline 67 & GR - Thessaloniki & 83 \\
\hline 68 & H - Magtarhaz Harbor & 83 \\
\hline 69 & GR - Thriasio Pedio Athens & 82 \\
\hline 70 & LT Mockavoa Terminal & 81 \\
\hline
\end{tabular}

\section{Conclusion and recommendation}

The engagement of the public sector in the funding and the strategic planning (overall concept) of the Freight Villages is a crucial factor for the economic sustainable success in the development of such locations. And this engagement seems to be worth it, as a look on the dense network of high performing Freight Villages in Western Europe proves. After the implementation of sufficient infrastructure, the acceptance of the economic sector was often very easily achieved. But the first step in the development was taken by the relevant authorities on national or regional level. This survey shows, that the Freight Village idea has spread itself extensively across Europe which will go on in the next years - as can be seen by the yellow marked locations in the following map.

How could be the ranking continued in the future? For example, the development of a worldwide "rough"-ranking, based on only some criteria, could be projected. This global ranking could have as a result a notable visibility in the logistics community and in the corresponding media. It may be also interesting for port users and for business and institutions related to port industry. The ranking of the dry ports is very important at policymaking level, as in this way good practices identified. Furthermore, the position of each dry port at the international level can be explained and understood as well. Consequently, it is necessary to construct indicators which use those data that will deliver the degree of sustainability of each dry port, while simultaneously will make the comparison between international ports feasible (Agallos, 2016).

\section{Acknowledgments}

$\Rightarrow$ Supported by the ÚNKP-17-4 New National Excellence Program of the Ministry of Human Capacities.

\section{References}

Agallos, I.-C. (2016). The contribution of ports in regional development: Comparative estimates via indicator of port sustainability. Thesis, Athens University of Economics and Business. https://doi.org/10.13140/RG.2.2.20796.44167

Ducruet, C. (2009). Port regions and globalization. Aldershot: Ashgate. [Online]. Available from: https://halshs.archives-ouvertes.fr/ halshs-00458071/document [Accessed: 12th July 2017]

Hanaoka, S., Regmi, M. B. (2011). Promoting intermodal freight transport through the development of dry ports in asia: An environmental perspective. IATSS Research. 35(1), pp. 16-23. https://doi.org/10.1016/j.iatssr.2011.06.001

Hesse, M. (2004). Land for logistics: Locational dynamics, real estate markets and political regulations of regional distribution complexes. Tijdschrift voor Economische Sociale Geografie. 95(2). pp. 162-173. https://doi.org/10.1111/j.0040-747X.2004.t01-1-00298.x

Hesse, M., Rodrigue, J.-P. (2004). The transport geography of logistics and freight distribution. Journal of Transport Geography. 12(3), pp. 171-184. https://doi.org/10.1016/j.jtrangeo.2003.12.004

Hilling, D. (2005). Transport and developing countries. Taylor and Francis e-Library, London and New York, Routledge. 
Juhel, M. H. (1999). The role of logistics in simulating economic development. Paper presented at the China Logistics Seminar, Beijing. [Online]. Available from: https://trid.trb.org/view.aspx?id=691888 [Accessed: 12th July 2017]

Korovyakovsky, E., Panova, Y. (2011). Dynamics of russian dry ports. Research in Transportation Economics. 33(1), pp. 25-34. https://doi.org/10.1016/j.retrec.2011.08.008

Li, J., Jiang, B. (2014). Cooperation performance evaluation between seaport and dry port; case of qingdao port and xi'an port. International Journal of e-Navigation and Maritime Economy. 1, pp. 99-109. https://doi.org/10.1016/j.enavi.2014.12.009

$\mathrm{Ng}$, A. K., Cetin, I. B. (2012). Locational characteristics of dry ports in developing economies: Some lessons from northern India. Regional Studies. 46(6), pp. 757-773.

https://doi.org/10.1080/00343404.2010.532117

Nguyen, L. C., Notteboom, T. (2016). A multi-criteria approach to dry port location in developing economies with application to Vietnam. The Asian Journal of Shipping and Logistics. 32(1), pp. 23-32. https://doi.org/10.1016/j.ajs1.2016.03.003

Notteboom, T., Rodrigue, J.-P. (2009). Inland terminals within north american and european supply chains. Transport and Communications Bulletin for Asia and the Pacific. 78(1), pp. 1-39. URL: http://www.nttfc.org/reports/ intl/Development $\% 20$ of\%20dry\%20ports\%20b78_fulltext.pdf\#page=11

Omiunu, F. G. (1989). The port factor in the growth and decline of warri and sapele townships in the western niger delta region of nigeria. Applied Geography. 9(1), pp. 57-69. https://doi.org/10.1016/0143-6228(89)90005-2
Panova, Y., Hilmola, O.-P. (2015). Justification and evaluation of dry port investments in russia. Research in Transportation Economics. 51, pp. 61-70. https://doi.org/10.1016/j.retrec.2015.07.008

Rahimi, M., Asef-Vaziri, A., Harrison, R. (2008). An inland port location-allocation model for a regional intermodal goods movement system. Maritime Economics \& Logistics. 10(4), pp. 362-379. https://doi.org/10.1057/mel.2008.17

Roso, V., Woxenius, J., Lumsden, K. (2009). The dry port concept: Connecting container seaports with the hinterland. Journal of Transport Geography. 17(5), pp. 338-345. https://doi.org/10.1016/j.jtrangeo.2008.10.008

Rutten, B. J. (1998). The design of a terminal network for intermodal transport. Transport Logistics. 1(4), pp. 279-298. https://doi.org/10.1163/156857098300155278

Shi, X., Li, H. (2016). Developing the port hinterland: Different perspectives and their application to shenzhen port, china. Research in Transportation Business \& Management. 19, pp. 42-50. https://doi.org/10.1016/j.rtbm.2016.05.004

Wang, G. W., Zeng, Q., Li, K., Yang, J. (2016). Port connectivity in a logistic network: The case of Bohai bay, China. Transportation Research Part E: Logistics and Transportation Review. 95, pp. 341-354. https://doi.org/10.1016/j.tre.2016.04.009

Witherick, M. (1981). Port developments, port-city linkages and prospects for maritime industry: A case study of southampton. In: Hoyle, B. S., Pinder, D. (eds.) Cityport industrialization and regional development. (pp. 113132.) Pergamon Press, Oxford. 